\title{
The good enough mother under social vulnerability conditions
}

\author{
A mãe suficientemente boa em situação \\ de vulnerabilidade social
}

\author{
Michele Carmona ACHING ${ }^{1}$ \\ Tania Mara Marques GRANATO
}

\begin{abstract}
The present qualitative study aims to understand the affective and emotional attitudes that support the maternal experience in precarious conditions by articulating the maternal ideals of socially vulnerable women through the Winnicottian concept of the good enough mother. We used a procedure called Interactive Narrative to facilitate a less defensive and more ludic approach to the studied theme and invited women sheltered in an institution for pregnant and puerperal women to complete a story that had been written by the researcher. In the second stage, we formed a discussion group to gain insight into participants' conceptions of motherhood. The material produced was analyzed as a collective production so that we could identify underlying affective and emotional aspects of the group's imaginative elaborations about motherhood in precarious conditions. Feelings of helplessness, abandonment and loneliness were as present in the narrative productions as the idea that having a child creates opportunities for the development of maternal capabilities.
\end{abstract}

Keywords: Interactive narrative; Motherhood; Psychoanalysis; Social vulnerability.

\section{Resumo}

Esta pesquisa qualitativa busca compreender os sentidos afetivo-emocionais que sustentam a experiência materna em condições precárias ao articular os ideais maternos de mulheres em situação de vulnerabilidade social ao conceito winnicottiano de mãe suficientemente boa. Fez-se uso de um procedimento denominado Narrativa Interativa para facilitar uma abordagem menos defensiva e mais lúdica do tema a ser investigado, convidando mulheres abrigadas em uma instituição para grávidas e puérperas a completar uma história pré-elaborada pela pesquisadora. Como segunda etapa propôs-se um grupo de discussão com as participantes, visando suas concepções a respeito da maternidade. O material coletado foi analisado como produção coletiva de modo a identificar aspectos afetivo-emocionais subjacentes às elaborações imaginativas do grupo sobre a maternidade em situação de precariedade. Sentimentos de desamparo, abandono e solidão permearam as produções narrativas, tanto quanto a ideia de que a experiência de ter um filho abre portas para o desenvolvimento de potencialidades maternas.

Palavras-chave: Narrativa interativa; Maternidade; Psicanálise; Vulnerabilidade social.

\section{$\nabla \nabla \nabla$}

1 Pontifícia Universidade Católica de Campinas, Centro de Ciências da Vida, Programa de Pós-Graduação em Psicologia como Profissão e Ciência. Av. John Boyd Dunlop, s/n., Jardim Ipaussurama, 13060-904, Campinas, SP, Brasil. Correspondência para/Correspondence to: M.C. ACHING. E-mail: <michele.aching@gmail.com>.

Article based on the dissertation of M.C. ACHING, intitled: "A mãe suficientemente boa: o imaginário de mães em situação de vulnerabilidade social". Pontifícia Universidade Católica de Campinas, 2013.

Support: Coordenação de Aperfeiçoamento de Pessoal de Nivel Superior. 
Emotional experience research, such as that conducted by Aguiar, Silveira, and Dourado (2011) has indicated that the scientific academic environment focuses on the regulation, characterization and standardization of emotional experiences. This focus is manifested in the search for causal relationships and the methods used to obtain data on the prevalence of the studied phenomenon. However, the scientific model is limited in its ability to address emotional issues, both in research and in clinical practice (Aguiar et al., 2011). In these contexts, more interest has been shown in muting the anguish than listening to it.

To understand the motherhood-related emotional experiences of young women, mothers and professionals, our research group employs narrative procedures in which participants are asked to imaginatively develop a given dramatic situation. Pontes, Barcelos, Tachibana and Aiello-Vaisberg (2010), used a similar technique (the Story-Drawing procedure) to study the collective imaginary of adolescents about early pregnancy. Similarly, Granato, Tachibana and Aiello-Vaisberg (2011b), interpreted Interactive Narratives about the motherhood experience that they had collected from obstetric nurses.

The term collective imaginary refers to a set of beliefs, emotions and images that a group produces about a specific phenomenon through shared experience of a situation or context that "operates both consciously and non-consciously in all human manifestations" (Ambrosio, 2013, p.55).

Imaginative productions about the motherhood experience reveal the plurality of attitudes that emerge from the affective and emotional impact that a given maternal conflict generates in study participants (Granato, Corbett, \& Aiello-Vaisberg, 2011a), in professionals (Granato et al., 2011b) or in groups of mothers living in precarious social conditions (Granato \& AielloVaisberg, 2011). These studies indicate that the maternal figure is still associated with dedication and unconditional love and is supposed to be responsible for the physical and mental well-being
The maternal role as it is currently conceived is the result of a long process of the construction of maternal models. Such models depend on an era's social expectations and include ideals, warnings and recommendations that guide maternal behavior and the attitudes of family members, professionals or social institutions.

Given the social inequality that characterizes Brazil, Gomes and Pereira (2005) focus on the attitudes of those living in homes and in families under precarious conditions: "marked by hunger and misery, the house represents a space of privation, instability and fraying of solidarity and sympathetic bonds" (p.359). When home ceases to offer protection and becomes a space of conflict, family members usually react in a fragmented and unhealthy way due to the absence of the emotional conditions and support networks that can help families to cope with adversity. Therefore, a vulnerability condition is established.

Lynch and Tiedje (1991) recognize that lowincome families develop unique family structures, communication processes and socialization strategies for their children designed to ensure their survival. When a family is exposed to "personal, social or environmental factors that contribute to or increase the probability of their members suffering from psychological disorders" (Prati, Couto, \& Koller, 2009, p.404), dysfunctional physical and/or emotional processes are potentiated and the family fails to establish a healthy basis for the development of its members (Prati et al., 2009).

Within Winnicottian psychoanalytical theory, a good enough environment is the basis of a child's emotional development (Winnicott, 1975a). This study examines the possibilities and limits on a mother's ability to be good enough (Winnicott, $1956 / 2000$ ) when she lives in socially precarious conditions.

Winnicott (1956/2000) describes the state of primary maternal preoccupation as a condition that is required but not sufficient for the mother to reconcile the baby's needs with maternal care. This care is improved by the sensitivity developed throughout the gestational period and reaches its 
apex in the post-partum period, when the mother is able to provide for the baby's needs.

Though Winnicott's theory is based on a different context than that of our patients (i.e., on a nuclear family that includes a woman who is devoted to her home and children and a husband who provides the family's income), we emphasize the Winnicottian claim that women require support from their partners, family and society to become good enough mothers.

In addition to contributing to the emotional resilience of individuals in moments of crisis, the family must be able to give continuity to the "unconscious dependence" (Winnicott, 1965/2005, p.137) experienced by children in their early relationship with their parents. This possibility of returning to a dependent role within the family allows mature adults to interact with social groups or institutions without losing a sense of personal continuity or excessively sacrificing their spontaneity.

Assuming that family and social support are essential to establishing healthy motherhood, which is crucial to the emotional development of individuals, it is necessary to study this process among socially vulnerable women. Considering the precariousness of this population's family bonds and social support and the idealized constructs about motherhood prevalent in society, we aim to psychoanalytically investigate how a group of socially vulnerable mothers constructs the image of a good enough mother.

\section{Method}

This qualitative study focuses on understanding a specific human phenomenon that occurs within a given context. This understanding is interpretatively produced by an implied researcher who is aware of his/her participation in the production of research data (Stake, 2011).

Our methodological choice to work at the interface between two methods - narrative and psychoanalytical -, is based on several assumptions. Regarding the narrative as a humanizing experience (Benjamin, 1936/1992) and instrumental in the construction of life experiences (Bruner, 2004; Ricoeur, 1999), we agree with Favoreto and Júnior Camargo's (2011) emphasis on the underlying meaning of this process and its "semantic and hermeneutic perspective that integrates, from a process and a dialogical perspective, subjects with their contexts and ideologies" (p.474).

Inspired by the psychoanalytical method, which uses the patient's narrative as a legitimate method for accessing personal experience, we chose to use the psychoanalytical approach throughout the study, applying it to the development of the narrative instrument, the record form used and the interpretation of the material produced during the dialogical exchange between researcher and participant.

The use of a narrative procedure in psychoanalytically oriented research is consonant with Aiello-Vaisberg's (2004) recommendations for presenting expressive procedures, "whose ludic aspect aimed to provide decreased anxiety and facilitate the perception of underlying psychological fields to the spontaneous collective expression" (p.107).

Thus, the use of a narrative procedure facilitates a less defensive and more ludic approach to the studied theme, benefiting from the transitionality - a concept proposed by Winnicott (1975b) as the third area of human experience -, through which a creative dialogue is established between a person's inner reality and the outside world.

Because of the affinities among narratives, emotional experience, and the Winnicottian psychoanalytical approach to the experienced drama (concepts briefly presented above) we adopted the Interactive Narratives procedure developed by Granato and Aiello-Vaisberg (2011). This procedure involves the use of a fictional story developed by the researcher to introduce an emotional conflict to the participant. The participant is then invited to freely and spontaneously complete the narrative and has the opportunity to imaginatively develop a personal solution to the presented drama. 
As a co-construction, the interactive narrative conveys, from the start, a field of affective and emotional senses that interrogates participants about their own emotional experience about motherhood. Invited to complete the story, each of the participants is asked to develop the presented plot toward an ending, according to their personal interpretation of the motherhood drama. Inspired by our clinical experience, we aimed to build a sufficiently verisimilar story that briefly and deeply related a conflict lived by a character whose context was similar to the daily lives of our participants (Granato et al., 2011b, p.83).

\section{Participants}

In total, 17 adult women participated in the present study. They were mothers who were staying in a shelter in the city of São Paulo, Brazil. This shelter hosts such women and their newborn babies during pregnancy, childbirth and post-partum. These women seek out shelters for different reasons, including abandonment by their partners or family, drug use, prostitution, abuse or because they are living on the streets.

\section{Instruments}

To analyze these women's imaginative elaborations about the good enough mother, we developed the Interactive Narrative presented below. This narrative includes elements of participants' daily lives, but its open-ended plot allows for personal appropriation of the story:

Cida had already been lying down for half an hour, but she had so many worries that it was hard to fall asleep. She imagined what the baby would be like, who the baby would look like and how she was going to take care of it, being alone. How would the birth be? Who would she tell when the labor pain started? She remembered the child's father, the passion they had experienced... Would he come back to meet his child? Among so many doubts, Cida fell asleep only to wake another nightmare! In the dream, she couldn't take care of her son. She could hear him crying from the cradle but couldn't get up from the bed. She tried, but her body wouldn't respond... With much effort, she dragged herself to the cradle, and when she was about to pick the baby up, the cradle turned over! Cida woke up terrified but was relieved when she noticed it had just been a dream. However, she still had a doubt: What kind of mother will I be?

In this narrative, the researcher used an associative movement of ideas and free-floating attention, based on her experience as clinical psychologist, to create a story that reflects the life experience of the participants. The narrative was based on the yearnings and anxieties shared by these women with their therapists in a clinical context prior to the present study. This dramatic content became the raw material for the development of an Interactive Narrative about a pregnant woman's dream and the multiple possible interpretations and possibilities it represents.

\section{Procedures}

After the objectives, procedures and justification of the present study were explained to them, the participants signed an informed consent form. The study was approved by the Ethics Committee of the Pontificia Universidade Católica de Campinas (Process no 213.776).

Three collective interviews were performed to accommodate participants in smaller groups. This was necessary because of the sensitivity of the theme and of the women's personal situations and also because of the depth of the group discussion that was expected to occur after the individual stories were completed during the second stage of the narrative procedure.

After 15 written and two oral interactive narratives were collected according to each participant's preference, the group discussion began with an invitation to share the affective and emotional attitudes triggered by the story and (re)constructed during the dialogue with the group and the researcher responsible for the present study. 
To record the group meetings, we adopted the strategy of writing transference narratives (Aiello-Vaisberg, Machado, Ayouch, Caron, \& Beaune, 2009), conceived as reports of the communications of participants as they are perceived by the researcher. This strategy results in a personalized and associative record that, more than recording the meeting, expresses the communication from the perspective of the researcher, who is aware of his or her own involvement in the production of the data.

Conceiving of psychoanalysis as a method for investigating the meanings of human experience, we applied the Winnicottian perspective to interpret the narratives developed by the participants and the transference narratives, exploring the participants' conceptions of the good enough mother.

\section{Results and Discussion}

\section{Affective and emotional fields}

Psychoanalytical narrative analysis allowed us to organize the narratives into affective and emotional fields, understood here as "well-defined psychic production areas" (Herrmann, 2004, p.61). These fields are constituted both by the individual psyche and by social and/or cultural determinations. These fields are presented below and have been assigned labels that communicate to the reader the thematic core around which the affective and emotional meanings expressed by the participants are organized to produce and communicate a personal motherhood experience.

\section{Field 1: Motherhood and helplessness}

Based on the discussion of the narrative material, we observed that for some of the participants, motherhood seems to contribute to the disorganization of a life that is barely supportable within the uncertainty of their social environments. One of the participants stated that when you have marital, financial or family stability, the suffering is mitigated even if you are constantly worried about "having something to eat, a place to sleep and about being both a father and a mother at the same time" (sic).

Many psychoanalytical studies (Folle \& Geib, 2004; Lobo, 2008; Pinto et al., 2011; Reis, Bonadio, Tsunechiro, \& Merigui, 2008) focus on pregnancy as an experience that prompts psychic maturity in women. Because attaining this maturity involves a complex and delicate transition, it is not always achieved.

In the context of precariousness in which the present study was conducted, the new emotional demands resulting from motherhood seem to potentiate an existing situation of helplessness. This finding corroborates the idea presented by Prati et al. (2009) that everyday events, such as pregnancy, become risk factors when a vulnerability condition is exacerbated.

Although we cannot generalize that every pregnancy is a risk factor under precarious conditions, the social context of our participants and the narratives and experiences shared in the discussion group indicate the fragility of their social condition. One of the participants stated that "all problems in our life end up interfering" (sic), referring to the fact that she cannot depend on support from her partner or her family. This statement conveys the impossibility of experiencing motherhood creatively, in the Winnicottian sense, and as an integrating factor of different life aspects.

Conversely, another participant concluded from the interactive narrative that the character Cida "was desperate... but she has her mother's family, who can help her take care of her child, so she knows she doesn't need to give up hope" (sic). This impression, i.e., that a difficult reality could be softened by family support, was shared by the discussion group. Unlike most participants, this participant received support from her family and even reported how much her mother had been helping her. She expressed gratitude for the shelter as an alternative to serving a sentence for drug trafficking.

It is well known that the difficulties faced by these women are potentiated by a pregnancy that, in a vulnerability context, necessitates a network of social and family support. However, the scarcity of resources they experience seems to mobilize them 
to seek, in the institution in which they are temporarily sheltered, for a more effective way of receiving the care required to face their pregnancy under precarious and lonely conditions.

The participants' reported experiences of helplessness indicate that the ties constituting these women's emotional environment do not live up to Winnicott's ideal (1965/2005) about the role of the family and other community ties as an extension of the mother's lap. Therefore, finding a "motherinstitution" is a relief to these women who do not have anyone available to care for or house them.

Winnicott (1965/2005) states the importance of adults being able to return to their families if necessary. However, in the vulnerability context in which the participants live, the most supportive measure the family can take is to look for an institution to replace them. Because the women's families are also victims of the social neglect that the participants are subjected to, the role of social work and psychology at the shelter has proven essential to reestablishing family and social ties and to meeting the emotional needs of these women.

\section{Field 2: I'm alone with this child, what now?}

After the pregnant women arrive at the shelter, having been abandoned by their families and/or partners, they realize that they are alone. Despite their feelings of helplessness and loneliness, these women decide to continue the pregnancy, though the prospect of motherhood seems lonely, as has been indicated by previous studies on motherhood (Granato \& Aiello-Vaisberg, 2011). One participant described the anguish of realizing that she was alone during such a crucial time: "I won't know how to take care of my son, being alone and abandoned. The child's father left me. I'm alone with this child, what now?".

In the studied population, it is common for husbands to abandon their wives after learning that the woman is pregnant and to never return. However, there are cases in which the partner returns to resume his role of father after the child is born, but this is atypical. Several excerpts taken from illustrate the suffering caused by this type of abandonment:

Abandoned, the child's father left me.

Cida thought so much about her husband that she had a nightmare, he abandoned her and she was dedicated to him, he didn't want anything to do with her or the child.

The helplessness that these women experience recalls Winnicott's idea of holding (1965/ 2005). Winnicott discusses the emotional needs of individuals sheltered by their families, who support them during moments of crisis. Such is assumed to be impossible in the participants' families, which struggle to meet many basic needs, such as housing, food and medical and psychological care.

According to our clinical experience in the shelter, when the pregnant women's mothers are reminded of emotional experiences by their daughters' pregnancy, these memories do not promote identification, which is the basis of maternal care. Instead, the mother's past experiences prevent them from advising the pregnant daughter about maternal care because they feel equally helpless.

A common characteristic of all of the participants' imaginative productions is the experience of loneliness. The researcher's narrative alludes to this problem, a strategy adopted due to the prevalence of this suffering in the studied population. However, most participants consider their own loneliness experience to be an integral part of their own story, confirming the suitability of the narrative structure developed for the present study. In addition, participants seem to have found a welcome figure in the researcher that conducted the study because they expressed sincere gratitude for the opportunity to be heard.

As participants discussed their loneliness, the paternal role, which is usually vague, often merged with the maternal role: "mother should be a father and a mother at the same time" (sic). In one of the narratives, a participant wrote, "she is already preparing to be a father and a mother at the same time, therefore a more attentive care". The father does not seem to take any responsibility for the 
child, which corroborates the findings of Granato and Aiello-Vaisberg (2013), requiring the mother to take full responsibility for the child. Winnicott (2002) states that given the demands of caring for a baby, the father "may not like the part he is responsible for and is not capable of dividing with the mother the huge responsibility that a baby should always represent" (p.15).

Tachibana (2011) agrees with the Winnicottian position that having a supportive environment makes the mother feel affectionate and concretely supported, allowing her to provide a welcoming environment for her baby. Considering the reports of abandonment and helplessness, it seems clear that even when the conjugal, family and social environment exists, it has failed to meet the participants' basic physical and mental health needs.

Among the strategies the participants used to compensate for the absence of the father, one of them was to express a sense of omnipotence: "even without a father, she has a body and a soul to worry about and fight as a mother and a father at the same time" (sic) because the environment refuses to support her. This woman "fights back her tears" (sic) and reorganizes herself for this experience of lonely care. Another solution is to stop loving the partner and transfer the love to her baby: "I'm going to think about the baby and keep in mind that who needs my love is the child... the safety of the child is what matters" (sic).

The search for the shelter, which is motivated by widespread deprivation, agrees with Gomes and Pereira's (2005) statement that families in precarious conditions do not offer a protective space for their members. The fraying of affective ties, already compromised by social vulnerability, prevents families from offering the physical and emotional care required for the development of family members' subjectivity.

Field 3: The mother is the one who does it, end of story!

The written and oral productions of participants suggest the preservation of the maternal ability to recognize children's needs. However, it is evident that physical needs tend to be prioritized at the expense of psychological needs, indicating that in this context of vulnerability, being a good enough mother is more closely related to Winnicott's concept of the handling (1949/2000), i.e., the management of the baby's physical needs. According to Winnicott, the mother expresses her love for her child through basic care. The participants of the present study were attentive to the basic needs of their children, overcoming their own limitations to meet them.

Winnicott (1956/2000) describes the state of primary maternal preoccupation as the withdrawal and dedication required for a woman to be aligned with the needs of her newborn baby. However, he warns that both the woman and her environment must be healthy so that she can enter or leave this preoccupation according to the baby's demands. How is this possible among mothers living in conditions as precarious as those of participants of the present study?

Although the women prioritize the needs of their children without considering their own feelings, the primary maternal preoccupation seems to motivate them to find personal resources to face adversity. One of the participants discussed the strength that women need to overcome obstacles, a strength they obtain from their own motherhood experience, and concluded that love for her children makes a mother capable of anything. One of the narratives expressed a rejection of the need that we all have for care, emphasizing that a child's helplessness mobilizes potentialities in the mother, helping them overcome their own helplessness:

I'm going to be the kind of mother that instead of thinking about the child's father, will think about the baby and remember that the baby is the one who needs me, and after all, he abandoned me and I decided that the safety of the child is what matters, and over time, I'll forget about the doubts and all my problems (sic).

This concept that even in conditions of precariousness, individuals can grow to support others is found in reports of maternal strength and preoccupation:

She swallowed her pride and fear and went hitchhiking at the Rodoanel [highway loop] to visit her child at the hospital. 
Worrying about what she can provide to the baby at the moment.

The need is more important than issues regarding feelings, we have to do it, end of story.

She thanked God, she will be a good mother because she is already worried about the safety of the child, who may not have a father, but has a good mother.

In addition, participants also reported in the discussion group the need to find personal solutions because of their precarious situations. They must ignore the medical recommendations about exclusive breastfeeding or the best milk for the baby because their employment keeps them from breastfeeding at the recommended times. Furthermore, financial limitations lead them to choose the cheapest products or privilege the care of one child over another. One of the participants described the difficult choice between buying diapers for the baby or yogurt for her one-year-old daughter.

\section{The good enough mother under social vulnerability conditions}

The identification of the affective and emotional fields present in the interactive narratives, discussion groups and transference narratives allows us to discuss the concept of the good enough mother in this social vulnerability context.

When Winnicott (1956/2000) conceived the idea of the good enough mother, he used as his reference the mid-twentieth century nuclear family in which women did not need to work outside the home and were dedicated to household chores and to caring for their children. The husband was the only income provider of the family and was fully dedicated to his occupation.

Winnicott (1956/2000) also knew that if women had no family income, they could appeal to the state and obtain help through social assistance services. The sheltered women who participated in the present study, in contrast, have no choice but to surrender to the care of a state that is more negligent than protective.
Thus, it seems frivolous to apply Winnicott's paradigm to women today, especially those living in social vulnerability conditions. Doing so could lead to the mistake of treating a deprived Brazilian family from the XXI century the same as an English middleclass family from the 1950s.

The good enough mother that arose from the present study lives in a society that demands maternal dedication but does not provide minimum well-being conditions. Thus, she needs to deconstruct the idealizations of the maternal figure, such as natural and exclusive breastfeeding during the first six months, followed by special milk and expectations of exclusive dedication to the baby during the first four months. Such women must meet other needs, such as paying bills, taking care of other children, working, traveling the long distances between home and work, lack of money, and lack of social and emotional support. The need to be mother and a father at the same time is added to this routine of leaving early and coming home late.

The good enough mother living in social precariousness conditions must accept that she is alone and helpless in her endless search for internal and external resources to overcome the obstacles of her condition and find immediate solutions for her basic problems, which leaves her little space to deal with emotional and existential issues.

These women report the experience of having to "swallow their pride" (sic), their self-esteem, to provide for their children. They can identify the needs of their children, especially their physical needs, which they struggle daily to supply. This is the definition of a good enough mother when facing such adversity.

Notably, under social vulnerability conditions, motherhood is experienced as helplessness, loneliness and uncertainty. This experience is usually marked by the absence of a partner, of a father to the child. The woman, despite being fragile, needs to find or develop resources to take care of herself and her child.

We agree with authors such as Fonseca (2012) and Ferrari and Kaloustian (1998), who note the increasing trend of women becoming the heads of single-parent families. Such trends weaken the 
maternal role due to the multitude of tasks the mother becomes responsible for.

However, the present study revealed the possibility of a satisfactory maternal care and the development of functional bonds between the mother and the baby even in a precarious social environment. Achieving this is not easy or simple, and it is unknown whether the good enough care can be sustained over time, but we imagine that being a mother in such precarious conditions must be an emotionally exhausting task.

The completion of the present study raised new questions, especially why, when facing such precarious circumstances, none of the participants mention the possibility of aborting the pregnancy. Although they have been abandoned, all of the women decided to continue the pregnancy, raising the question of what motivated this decision. Could the pregnancy offer a narcissistic fulfillment for the woman, which, added to the social value of motherhood, would lead her to adopt a subject position never before assumed?

These women also challenge us with their ability to overcome previous and current experiences of social helplessness, becoming able to reorganize themselves internally and externally and to engage in a primary maternal preoccupation that allows them to offer adequate care to their children.

If women are able to engage in primary maternal preoccupation, an emotional stage that distances the mother from reality as she focuses on meeting the baby's demands, this same dedication may be responsible for rescuing the possibility of dreaming and hoping. Does this explain why many women have so many children? After all, this dream often unravels as the precariousness of reality imposes, and it is possible that every pregnancy brings the possibility of starting from a new place, a more dignified place, a place of respect.

Pregnancy, childbirth and the postpartum period seem to rescue these women, even temporarily, from their daily suffering, allowing them to "forget" about it and focus on their children. Being responsible for someone who is even more helpless seems to lead some women to a "healthy" denial of their reality in favor of caring for a baby. However, we cannot deny the importance of the environment created by the shelter for expectant mothers and sheltered mothers. The provision of medical, psychological and social care allows motherhood to be experienced in a shared and supportive way so that the good enough mother can emerge.

\section{Contributors}

M.C. ACHING and T.M.M. GRANATO were involved in the conception of the study and design, M.C. ACHING, developed the Interactive Narrative and collected data. Both authors analyzed an interpreted data. M.C. ACHING and T.M.M. GRANATO revised the manuscript and approved the final version to be submitted.

\section{References}

Aguiar, D. T., Silveira, L. C., \& Dourado, S. M. N. (2011). A mãe em sofrimento psíquico: objeto da ciência ou sujeito da clínica? Escola Anna Nery, 15(3), 622-628.

Aiello-Vaisberg, T. M. J. (2004). Ser e fazer: enquadres diferenciados na clínica winnicottiana. Aparecida: Ideias e Letras.

Aiello-Vaisberg, T. M. J., Machado, M. C. L., Ayouch, T., Caron, R., \& Beaune, D. (2009). Les récits transférenciels comme presentation du vecú clinique: une proposition methodologique. In D. Beaune (Org.), Psychanalyse, Philosophie, and Art: Dialogues (pp.39-52). Lille: L'Hamattan.

Ambrosio, F. F. (2013). O estilo clínico 'ser e fazer' na investigação de benefícios clínicos de psicoterapias (Tese de doutorado não-publicada). Pontifícia Universidade Católica de Campinas.

Benjamin, W. (1992). O narrador: reflexões sobre a obra de Nikolai Leskov. In W. Benjamin. Sobre arte, técnica, linguagem e política (pp.27-57). Lisboa: Relógio D'Água. (Originalmente publicado em 1936).

Bruner, J. (2004). Life as narrative. Social Research, 71(3), 691-711.

Favoreto, C. S. O., \& Júnior Camargo, K. R. (2011). A narrativa como ferramenta para o desenvolvimento da prática clínica. Comunicação, Saúde e Educação, 15(37), 473-483.

Ferrari, M., \& Kaloustian, S. M. (1998). Introdução. In S. M. Kaloustian. Família brasileira a base de tudo (pp.11-15). Brasília: Cortez.

Folle, E., \& Geib, L. T. C. (2004). Representações sociais das primíparas adolescentes sobre o cuidado materno ao recém-nascido. Revista Latino-Americana de Enfermagem, 12(2), 183-190.

Fonseca, C. (2012). Ser mãe, mulher e pobre. In M. Del Priore (Org.), História das mulheres no Brasil (pp.510-553). São Paulo: Contexto. 
Gomes, M. A., \& Pereira, M. L. D. (2005) Família em situação de vulnerabilidade social: uma questão de políticas públicas. Ciência \& Saúde Coletiva, 10(2), 357-363.

Granato, T. M. M., \& Aiello-Vaisberg, T. M. J. (2011). Uso terapêutico de narrativas interativas com mães em situação de precariedade social. Psico (PUCRS), 42(4), 494-502.

Granato, T. M. M., \& Aiello-Vaisberg, T. M. J. (2013). Narrativas interativas sobre o cuidado materno e seus sentidos afetivos-emocionais. Psicologia Clínica (Rio de Janeiro), 25(1), 17-35.

Granato, T. M. M., Corbett, E., \& Aiello-Vaisberg, T. M. J. (2011a). Narrativa interativa e psicanálise. Psicologia em Estudo, 16(1), 157-163.

Granato, T. M. M., Tachibana, M., \& Aiello-Vaisberg, T. M. J. (2011b). Narrativas interativas na investigação do imaginário coletivo de enfermeiras obstétricas sobre o cuidado materno. Psicologia e Sociedade, 23(N. Esp.), 81-89.

Herrmann, F. (2004). Introdução à teoria dos campos. São Paulo: Casa do Psicólogo.

Lobo, S. (2008). As condições de surgimento da mãe suficientemente boa. Revista Brasileira de Psicanálise, 4(42), 67-74.

Lynch, I., \& Tiedje, L. B. (1991). Working with multiproblem families in intervention model for community health nurses. Public Health Nurse, 8(3), 147-153.

Pinto, R. M. F., Micheleti, F. A. B. O., Bernardes, L. M., Fernandes, J. M. P. A., Monteiro, G. V., Silva, M. L. N., ... Cohn, A. (2011). Condição feminina de mulheres chefes de família em situação de vulnerabilidade social. Revista Serviço Social \& Sociedade, 105, 167-179.

Pontes, M. L. S., Barcelos, T. F., Tachibana, M., \& AielloVaisberg, T. M. J. (2010). A gravidez precoce no imaginário coletivo de adolescentes. Psicologia: Teoria e Prática, 12(1), 85-96.

Prati, L. E., Couto, M. C. P. P., \& Koller, S. H. (2009). Famílias em vulnerabilidade social: rastreamento dos termos utilizados por terapeutas de famílias. Psicologia: Teoria e Pesquisa, 25(3), 403-408.

Reis, S. E. H., Bonadio, I. C., Tsunechiro, M. A., \& Merigui, M. A. B. (2008). O cotidiano de mulheres grávidas moradoras no alojamento de uma maternidade social. Texto \& Contexto Enfermagem, 17(3), 492-501.

Ricoeur, P. (1999). Historia y narratividad. Barcelona: Paidós lbérica.

Stake, R. E. (2011). Pesquisa qualitativa estudando como funcionam as coisas. Porto Alegre: Penso.

Tachibana, M. (2011). Fim do mundo: o imaginário coletivo da equipe de enfermagem sobre a gestação interrompida (Tese de doutorado não-publicada). Pontifícia Universidade Católica de Campinas.

Winnicott, D. W. (1975a). O papel de espelho da mãe e da família no desenvolvimento infantil. In D. W. Winnicott. O brincar e a realidade (pp.153-162). Rio de Janeiro: Imago.

Winnicott, D. W. (1975b). Objetos transicionais e fenômenos transicionais. In D. W. Winnicott. O brincar e a realidade (pp.13-58). Rio de Janeiro: Imago.

Winnicott, D. W. (2000). A mente e sua relação com o psique-soma. In D. W. Winnicott. Obras escolhidas: da pediatria à psicanálise (pp.332-346). Rio de Janeiro: Francisco Alves. (Originalmente publicado em 1949).

Winnicott, D. W. (2000). Preocupação materna primária. In D. W. Winnicott. Textos selecionados: da pediatria à psicanálise (pp.491-498). Rio de Janeiro: Francisco Alves. (Originalmente publicado em 1956).

Winnicott, D. W. (2002). Os bebês e suas mães. São Paulo: Martins Fontes.

Winnicott, D. W. (2005). Família e maturidade emocional. In. D. W. Winnicott. A família e o desenvolvimento individual (pp.129-138). São Paulo: Martins Fontes. (Originalmente publicado em 1965).

Received: January 24, 2014

Final version: June 30, 2014

Approved: September 9, 2014

\section{ERRATA}

Na página 15, Onde se lia:

A mãe suficientemente boa em situação de vulnerabiliade social

Leia-se:

A mãe suficientemente boa em situação de vulnerabilidade social 